УДК 338.48 (063)

\title{
"WINE" TOURS BY EUROPE AS ONE OF THE AREAS OF RECREATIONAL ACTIVITIES
}

\section{Larisa Savranchuk}

\author{
Yuriy Fedkovych Chernivtsi National University, \\ M. Kocubynskiy Str., 2, UA - 58012 Chernivtsi, Ukraine
}

The term "wine" tourism and its essence are considered in the article. Program, duration and types of "wine" tours are described. Principles of organization of such tours and the term of pre-order are determined. The attention is focused on the process of tasting, that includes: the location, the quality of the material, content; features and traits of enoteks, museums and wine festivals are highlighted; examples of classification "wine" tours (group, individual, hybrids first and second) are given. The data on the structure of "wine" tours (move to the starting point of travel, transfers, accommodation, catering facilities, and excursions) are presented. It refers to additional features over the standard program. Examples of car travel by the "wine" roads of France, "wine" routes in Italy are given. "Wine" tours of European countries, particularly in Cyprus (history's most famous brands, festivals, "wine" routes, the Museum of wine) are described. The excursion to the Greek winery, the link between wine and culture of the Italians and their character are delineated. The competitive principles of annual ceremony of marking of the best restaurant for "wine" tourism; culture center of the wine, "wine" estates in Italy are described. The attention is concentrated to the history of the brand "Chianti", production of grappa and other. The feast of the grape in Spain (dates, location, program of "hero" holidays) are discussed in the article. Peculiarities of climate and soils of Southern Spain are mentioned as factors of growing vines "Palomino", the role and value of "noble" mold in the production of heres, the features of the technology. The regions of wineries of Spain; the largest museum in the world of wine; specific accommodation facilities "Bodega"; symbiosis SPA hotels and restaurants; recreational coverage of Panades are mentioned in the article. The examples of production of the original Porto - the Sunny nectar of Portugal in Douro valley are given. Extra motivation to visit "wine" tours in Portugal are stated. The data about the culture of wine consumption in France are presented. "Wine" tours in Bordeaux, Champagne, Burgundy and Luarska Valley, Alsace and "wine" marathons of Medoc are described. Features of "wine" tours in Germany, classes of wines quality, wine-growing region, "wine" parks are highlighted.

Geneva wine region of Switzerland, which is a UNESCO World Heritage Site are characterized in the article. Attention is concentrated to the "wine" tours in Hungary (22 wine regions). Underdeveloped areas "wine" of tourism in Georgia are revealed. "Wine" tours in Transcarpathian and Odessa regions of Ukraine are described.

Key words: "wine" variety of gastronomic tours as direction of recreational activities.

Particularly resistant and very large segment of the world tourist business connected with gastronomy (culinary and wine) tours. Habitual customers for such tours are middle-aged and older, many women among tourists. "Wine" tour is a kind of "passive" recreation which oriented towards people who are not prone to stress condition in large cities such as London and New York, or the incredible adventure in the African Safari. "Wine" tourism is tourism that aims to (or attracts) tasting, consumption, purchase wines directly at the winery. "Wine"

(C) Savranchuk L., 2015 
tourism may include visits to wine production, vineyards, famous restaurants, wine festivals and other special events [1, p. 325-328].

Program of wine tour can include various elements. Often it includes sightseeing tours and visits to vineyards, wine campaign to concern and participation in the thematic cultural events, such as wine in the holy [2, p. 7-9]. Wine tour usually lasts no more than a week, but there are trips that are only two or three days. They can be involved to wine festivals. Also travel agencies offer individual order wine tour, which aims to familiarize professional specialists [3].

"Wine" tourism has a few simple principles. One of the most important - taste wines only in places of their production. In any place in the most popular wine tourism enjoy typical local grape varieties, especially those that are unique to the area. Among wine lovers there is a perception that wine than the "left" the place where it is "grown" and ripe, the worse it tastes. Most of all when traveling spoiled wine, sometimes transported in tanks that badly affects the taste. Hence the conclusion - a real French wine can taste only in France, so foodies who are engaged in wine tourism, there are no long distances (for example, a large number of tourists plan their gastronomic tour for 5-6 months) [4]. This general principle wine tourism best suited to excursions to wineries with wine tasting in special rooms (so-called "wine tours"). Today, many wine home in resort towns, villages have the such halls. You can try the wine and cognac with a guarantee of quality. In addition, the tasting visitors will learn a lot of interesting and useful information about the wine region, the history of wine making, skills are right wine consumption. Also offer to tourists technological culture production, fall in cellars with huge barrels acquainted with the mystery maturing wines, learn about ancient traditions specific farm [5].

Some businesses have a huge collection of wines. They are called enoteca. They can have $1 \mathrm{mln}$. Bottles. In addition, many enterprises are organized wine museum where you can learn about the history and characteristics of a wine-making certain areas. Visiting museums involved in the wine tour. Leading travel companies offer world to visiting tasting rooms, tours to wineries, and visits to wine festivals and even special multi-day programs - wine tours with visits to several companies. Depending on the wishes travelers can organize the following trips:

1. Individual tour. It can organize travel company (usually the most expensive version), or by the tourist (there is risk of not what you expect). These types of wine tours are good for those who do not want to depend on a group of people and be free in his decisions and movements.

2. Group tour. Organized travel company for a group of people specifically, or after the typical route for everyone. Group tours are usually well organized "and from" and does not involve changes in the program.

3. Joining the group. A great option for those who want to relax individually and the time to reconcile with the group journey on the wine route. In this case, tourists decide where they will rest and with whom getting the opportunity to get a well organized tour.

Any wine tour consists of a standard set of tourist services, complemented by gastronomic components:

1. International air flight or any early move to a place of wine travel - by train, car, etc.

2. Transfer. He bought in advance or on arrival. It is always important to know the details of such a move, because the wineries are usually found in remote areas (transport, which brings tourists from the airport to the hotel and back). 
3. Accommodation in a hotel or guest house winemaker. Depending on the preferences of tourists, placing it in a certain category of hotel. Also, some "wine houses" have its hotel infrastructure, where, for a fee, can be accommodated. In winemakers add "flavor" to the trip.

4. Meals (gastronomic component).

5. Visit the winemaking and wine tasting. This is a mandatory part of any wine tour and one of the nicest. Typically, a visit to the winery is: visiting vineyards detailing the location and characteristics of the soil; visiting wineries and cellars; visiting winery museum, if any; wine tasting. During the tasting tourist learns about: features of a wine; differences from other wines; which take the best dishes this wine; teach him to recognize the taste nuances. It is quite possible personal acquaintance with the owners of wine growing, but it is advisable to negotiate beforehand. Depending on contingent travelers winemakers themselves decide which wine to represent and how much to go into professional nuances. Most wineries wine can be purchased on site.

6. Additional services. Additional services include all that goes above and beyond the standard program; museums and galleries, yachting and boating; trip to the theater; fishing trip; flying on balloons or beach holiday.

Autotravels on "wine roads" with visiting castles, vineyards, wine producion and restaurants attract huge number of tourists from around the world. The advantages of this type of tourism - the ability to plan a route with a "card in the hands". However, the largest and most famous French vineyards only accept group tours and only by prior arrangement with a particular travel agency. Almost all countries have such wineries "wine roads" leading from the castle to castle, from winery to winery. In Italy laid special routes with names "Strada del Chianti", "Strada del Vino", pleasant for fans of wines.

Wine tours Europe. Ever since the founding of wine production in Cyprus, which is thriving and still, the most famous wine brands produced under KEO and ETKO. The most popular Cypriot wines today are: Chardonnay, Sauvignon Blanc, Riesling (white); Cabernet Franc, Carignan Noir (red) and others. In September, held in Cyprus wine festival, which lasts 10 days. Organized by its municipality of Limassol, the largest center of winemaking in Cyprus, in the municipal garden. For Cyprus are special wine routes: three in the vicinity of Limassol and one - in the district of Paphos. In 2001 the island was opened Wine Museum (in Erimo), where you can try all kinds of brands produced in Cyprus wines. After the wine tasting you can buy them here.

Known to the world and Greek wines. On the island of Rhodes, there is wine factory, where tourists organize excursions and local wines on offer at their cost (average \$ 2-3 per bottle).

In Italy there is a special relationship between wine, culture and nature of the population of people living on this earth. As a result of the special annual ceremony, which takes place at the Palace of the Medici, in Florence, celebrated winning the places that in the past year become the most popular objects wine tourism of the country. Thus, the best restaurants for wine tourism in 2010 was the establishment in Florence "Wine country". It is widely known not only excellent selection of wines, but also traditional cuisine and atmosphere of comfort. The best facility that combines culture and wine, in 2010 awarded "Wine Culture Center", located in a picturesque location, among vineyards and olive trees. You can read the history of Tuscan wines. This establishment is located in Montespertoli. Among the best parks, gardens and architecture Italy - Villa "Magic wine", which is located in Tuscany. Among the wine estates of land is one of the oldest, and certainly the most beautiful. It is made Italian wine - "Chianti", which gained popularity, including due to a successful brand, recognizable 
everywhere convex bottle braided straw. "Chianti" the first time was mentioned back in 1716 in the area were put severe demands on the quality of product produced. Chianti emblem known to most connoisseurs of wine around the world - "black cock". This sign of compliance with all quality requirements and production technology. Veneto Region, whose capital is lovely unique city of Venice - the largest producer of the best Italian wines, offering their entire range. Best Italian grape vodka-grappa Nonino should try to - where there is a real business model from the production of strong drink. Tourist route Friuli - Venice Julia famous for its white wines, which can be estimated by visiting the local wine economy; where you can contemplate the unique yeast room where valuable cultivated fungi. Italy is considered to be a world champion for a variety of wines. The country has grown more than 300 varieties of wines. Leaders are areas of Tuscany and Piedmont.

The calendar of the Spanish province of Andalusia on September 10 of each year holds a special place. On this day in the town of Herez de la Frantera for many years and even centuries begins harvest festival dedicated to vintage. Originally bunch consecrated and then squeezes juice bare feet to the sound of old songs. By Happy Holidays readily attracted tourists from all over the world. The culprit national holiday "heres" - wine that is known far beyond Spain. It is produced from a rare vine variety "Palomino". An important role is played by unique climatic and soil conditions of southern Spain. In this sort of grapes "fell in love" mold, which naturally provides specific fermentation juice. It takes a lot more time before heres "matures" and poured in the bottles. Before that, experts determine the quality of the content of each barrel where "live" this drink. By the way, sampling is an interesting spectacle for tourists and requires considerable skill from the performers: the astringent liquid immersed special cylindrical container on a long slender arm, trying to grab mold. And then deftly without a miss, sending a thin stream into the glass, which is located in another hand, lifting capacity overhead. This should not spill a drop. Heres - a whole family of grape nectars. It is similar to its counterpart from Portugal - Porto. The most famous wine-making region of Spain is Roha. It is synonymous with excellent Spanish wines. It is part of the modern Rohy lived Romans, who laid the foundation of local wine. Roha is the first wine region, which was officially recognized by the Spanish government. An interesting for tourists is the largest museum in the world of wine - museum Vivanco dynasty Winery. In the Roha is a unique opportunity to combine a love of comfortable living and love of wine, settled in a hotel in "Bodega"-Wine. The farm where Marcus Riskalya a restaurant, HotelSPA in one "bottle". There is also a SPA-hotel, located beside to the Museum of wine (Villa Lucia). Castilla and Leon - the largest area of production of the Spanish wines. On its territory there are about 200 wineries. Fans of white and sparkling wines are well aware Panades region in Catalonia, because it is considered the birthplace of the famous refreshing "coffee". Panades as a wine region, known since ancient times, but the best wine he was producing only 20 years. The main advantage of the city in terms of tourism - its relative proximity to Barcelona (about an hour drive).

Porto - wine, which the Portuguese called solar proud nectar, drink of gods. This drink for centuries decorated tables royals. In Portugal, he covered many legends that attract the attention of tourists. Red and white porto still made only from grapes harvested to cut into the rocky mountains near the coast Douru terraces, and everything else is regarded as a fake. The unique microclimate in the north of Portugal differs hot hot summers and very cold winters. Total area Douru Valley, often called the "wine country" - about 240 thousand ha. Harvesting grapes from vines undersized starts from late September to the first days of 
October. From the surrounding villages gather farmers, is in a festive mood to hear old folk songs. Wine is poured into oak barrels noticing each one corresponding certificate and driven in cellars. This huge wooden containers and bottles "Monitor" porto wine experts and employees of manufacturers and experts. Each export company has its own cellar, most of which are open to tourists and tasting. Along with the famous port wine produced in Portugal, Madeira, Heres, Muscat, dry table wines that are sometimes inferior in quality Italian, French and Spanish wines, and unique slightly carbonated "green wine". But the glory of this small state wine country offer is its port, although generally in proportion to its territory by the number and quality of wines Portugal ranks first in the world. How popular Portuguese wine around the world, as the Portuguese retain their cooking secrets. Only a few brands of highquality wines are allowed to export. The remaining grape treasures kept in the country as public values, and to taste of them, tourists have to go to their homeland.

France - country of gourmets where cheese and wine consumption is part of the national culture. French open bottle of good red wine for an hour or two to the feast to wine enriched with oxygen and revealed the whole bouquet of taste. White wines and champagne are served at 8-10 (at higher temperatures because of their taste of disappearing). Red wines are served at temperatures above 18. As for storage, after transportation of bottles in transport, especially in the airplane, the French drink wine, try and wait a week to give him a "rest". This country is by far the most popular in terms of "wine tourism": the tourist market offer special tours with accommodation in castles Bordeaux, Champagne, Burgundy and Luarska valley. Region "Médok" - is one of the famous wine production in the world. It annually produces more than 112 million bottles. The most popular in the world enjoy red wines from this region. With the "Big Five" - 4 wineries are located here. It is carried out "wine" marathons. During the trip here, "wine" tourists acquainted not only with the production in the Medoc, but the most famous regions of Bordeaux. Alsace - unique place, historically combines elements of French and German cultures. The region, famous for its "wine" expensive and finest white wines varieties "Muscat", "Riesling". The best wine producers of Alsace surprise the most demanding gourmet - one of the first farms abandoned the use of chemical interference in the process of creating wine. The town attracts tourists Marlenheym old peasant farms winemakers. Valley Rhone safely be called winy. The vineyards are located in the valley from north to south. It is the oldest area of processing grapes, known in the IV-VI centuries B. C. thanks to the Greek civilization. But only at the beginning of the XX century Ronski wines meet the highest requirements were the wines of France. To complete the experience, making wine tours, firms combine a trip to the valley of the Rhone and Provence.

Also, a considerable place in the wine tourism occupy Austria and Germany. In Germany the worst climatic conditions for growing grapes. The vineyards are located on south facing slopes of riverine: water mirror reflect heat, helping to maintain the desired temperature for ripening berries. A cold autumn mist arising from rivers, protecting the vines from the devastating early frost. The German wines are four classes of quality. The easiest table wine produced exclusively in Western Germany - officially registered with grapes. Steps above - landvayn - wine produced in one of the wine regions. Next - quality wine from certain regions: it include most German wines. The law of 1971 Germany is divided into 13 wine-growing regions where arrange special tours for tourists in areas wine production. Each of them is unique. Germany's largest wine-making region is considered Raynhessen situated in a valley between the hills east of the Rhine. More than $90 \%$ of local wines - 
white. "Wine Road of Germany" lies between the Rhine valley and hills covered with forest. It is the oldest and most famous tourist road across the country. It provides a break from everyday life and walk winemakers courtyards. Especially remarkable experiences available from the last week of August, when the wine road is closed to cars, and all winemakers courtyards open to tourists. Then this is the place turns into a real "wine park", which just need to get everyone who appreciates wine tourism. Not far from the road in Bad Durkheim is the world's largest wine barrel $(1.7 \mathrm{mln}$. 1.), which is now a restaurant. Wine winding road, passing through towns, villages and yards winemakers at every step and there is a stop for wine tourism. Many tasting bars, wine restaurants, wine cellars await lovers.

Swiss chocolate, cheese cause a good impression in every person. Swiss wines are less famous - but this is another pride of the country, which it is proud. The main wine region of Switzerland even included in the UNESCO World Heritage List. Its vineyards are located on the shores of Lake Geneva and take territory from Lausanne to Montreux. Reported wines produced in eight districts of the region. Introduction to wine grapes and begins with a tour of the castle of La Doges, which was built in the XVIII century. Adjoining the winery can be visited only wine tour. Most of the wine produced in the region of Schasla variety that is most popular in Switzerland. On the shore of Lake Geneva climatic conditions allow him to get incomparable taste. That little degree, floral wine with a variety Schasla brought fame to this region.

Hungary - a country where wine culture is developing originality from the beginning of settlement of this area. The most favored local wines are tough and astringent. Their fame spread throughout Europe. Known worldwide Tokaji, which was the epithet "royal". Traditions wine consecrated by centuries of experience of local craftsmen. A total of 22 winegrowing regions of the country. Balaton - the most famous wine regions from all over Hungary. It is on its territory are five famous wine lands. Wine, the taste of which incorporates the beauty of the Mediterranean climate and the specific local soil. That local soils of volcanic origin offers such unusual taste wines and imbues them useful minerals. Preferably in this region grown white grape varieties, some of whom are celebrities "Chardonnay", "Sauvignon", local varieties, as well as the newly displayed such as "Zenit". Wine tours are on the edge of the valleys long extinct volcanoes. The "Wine Road" provides the opportunity to taste the wines and wineries to visit, to see the sights.

Georgia is one of the underdeveloped areas of wine tourism. Although the Caucasus has long been known for its winemaking traditions and hospitality. According to experts, the history of Georgian wine has at least eight thousand years. The most famous wine tours seven days"Wine Road of Georgia". Its route starts from Tbilisi and passes through Mshetu to Borjomi. In Tbilisi tourists visit the factory of sparkling wines "Bagrationi 1882", which acquainted with the history of the factory, a tasting room partaking 12 kinds of sparkling wine, savoring lavash bread, fruits and cheese.

In "Hurdzhanskiy house wine" tourists are involved in the local baking bread, cooking shish kebab, khachapuri and production of grape vodka. The most famous Georgian white dry wine is "Tsinandali". The name comes from the town in Kakheti, where special climatic mikrozona. Made from Rkatsiteli grapes. The most famous among Georgian semi-sweet wines are red. Overall, there are dozens of names of wines. Thus, only the company "Tamada" offers 30 items.

As for Ukraine, there can be distinguished wine regions of Transcarpathia and the Southern region. Each year, in the Transcarpathian region celebrated the feast of wine. It 
is the only region of Ukraine, where the tradition has taken root. As in France, this is the third week of November, only the French celebrate on Thursday, and in Transcarpathia - on weekends. From the most developed wine regions this is different in that there is almost no powerful plants. Winemaking region presents small private winery where wine is usually produced by ancient technology and meet guests and accompany the owner, who is also chief winemaker. The main areas of wine in Transcarpathia - Berehovo, Mukachevo, Uzhgorod and Vinogradov. Recently, the coast, wine tasting opened 300 years "Old cellar". There are tourists on the history of winemaking in Beregovo, which dates back more than 1000 years. Then invite visitors directly into the cellar, which features a covered table. Here is the actual tasting: it 5-6 kinds of wines of own production. This is mainly fine wines, aged for at least 1-5 years from the time of harvest. Also, a survey of one of the publications of Transcarpathia, over $30 \%$ of tourists coming to the region want to try mulled wine with Zakarpattya. Recently, the local Union of private growers and winemakers Transcarpathian created "Wine Road". In union united skilled winemakers from Hungary, Mukachevo and Beregovo. This will include private cellars winemakers whose products pass mandatory certification. For tourists "path" will be another interesting highlight of the region. "Chardonnay" - the first Uzhhorod tasting room. The wine cellar is located in the ancient city near the unique medieval castle. Today only here in the tasting room "Chardonnay", gathered in one place the best Transcarpathian wines and cognacs. At the court of connoisseurs drinks are as legendary "Roses Transcarpathia" and exclusive varieties, which shall not taste anywhere else. Agroindustrial company "Leanca" named after the grape variety, which for many years made famous Transcarpathian wine - "Serednyanske". But it is not only known in Ukraine and in the world winery. "Cabernet", "Radiant", "Pearl of the Carpathians", "The Rose of Transcarpathia", "Temptress" - two dozen wines brought fame Transcarpathian winemakers at many international competitions. An example of modern winemaking complex Southern region of Ukraine is the "Shabo" in the Odessa region. Created this company "Shabo Wine Cultural Center" invites everyone to an unforgettable journey through the pages of the history of winemaking, where you can witness the revival of traditions of winemaking and learn the secrets of creating noble beverage. Shabo is an ancient wine region where the grapes are grown from the XII century french masters vine. At the beginning of the XIX century there was a colony founded by French-Swiss immigrants. Shabo is located on the so-called "grape latitude" with the world as the vineyards of Bordeaux and Burgundy.

Each year, wine tourism is becoming more popular. First, it's a good excuse to extend the holiday season without the sea. Peak visits to wine routes accounts for autumn. Objective reasons is a vintage and festivals dedicated to the new wine season. Secondly, wine tourism tourist advertised brand (thanks not only wine producers, but producers tourist product). Thirdly, wine tourism is of particular relevance in light of recent forecasts, by which time which people allocate to their holidays, will shrink, so tourists will seek tourism product that gives maximum impressions in the minimum of time.

Today, reduced total wine consumption low grade species, of which the French say they "leave stains on the tablecloth and holes in the stomach". Qualitatively same varieties produce and consume more and more. To date, the most popular country in terms of "wine" France is tourism: the best travel companies offer "wine" tours with accommodation in castles Bordeaux, Champagne, Burgundy and Luarskoyi Valley. True wine tourism designed for those who are interested not so much the product as the mystery of its origin and manufacturing process chain. True connoisseurs of wine, wine tours perceived as an 
opportunity to touch the ancient traditions and enjoy the special atmosphere of communication. The greatest interest among professionals and amateurs causing wine tours to Italy and France, which after visiting every new member of the tour revises its attitude not only to drink, but the culture of consumption.

\section{СПИСОК ВИКОРИСТАНОЇ ЛІТЕРАТУРИ}

1. Басюк Д. I. Винний туризм як інноваційний напрямок туристичного ринку / Д. І. Басюк // Здобутки, проблеми та перспективи розвитку готельно-ресторанного та туристичного бізнесу : Всеукр. наук.-практ. конф., 29-30 жовтня 2012 р. - К. : НУХТ, 2012. - C. 325-328.

2. Маслов E. C. Разработка модели эффективного управления винного туризма /

Е. С. Маслов // Культура народов Причерноморья. - 2006. - № 83. - С. 7-9.

3. http://wineworld.ru/interes/history/birthwine/article92.html

4. http://winelist.ru/vinnyi_turism.html

5. http://wineworld.ru/interes/history/birthwine/article92.html

\section{REFERENCES}

1. Basyuk, D. I. (2012). Wine tourism as an innovative tourist market direction. Proceeding from: Achievements, problems and prospects of development of hotel and restaurant and tourism business. Kyiv: NUFT, 325-328.

2. Maslov, E. S. (2006). Razrabotka modeli effektivnogo upravlenija vinnogo turizma. Kul'tura narodov Prichernomor'ja, 83, Simferopol, 7-9.

3. http://wineworld.ru/interes/history/birthwine/article92.html

4. http://winelist.ru/vinnyi_turism.html

5. http://wineworld.ru/interes/history/birthwine/article92.html

Стаття: надійшла до редакиії 07.09.2015

доопрацььована 12.11.2015

прийнята до друку 03.12.2015

\section{“ВИННІ" ТУРИ СВРОПОЮ ЯК ОДИН 3 НАПРЯМІВ РЕКРЕАЦЙННӦ̈ ДІЯЛЬНОСТІ}

\section{Лариса Савранчук}

Чернівецький начіональний університет імені Юрія Федьковича, вул. М. Кочюбинського, 2, 58012, м. Чернівиі, Україна

Розглянуто поняття “винний” туризм, його суть; описано програма “винного” туру, його тривалість, види; схарактеризовано принципи організації таких турів, терміни замовлення; сконцентровано увагу на процесі дегустації, зокрема: розкрито місцезнаходження, розглянуто якість матеріалу, згадано інформаційне наповнення (ідеться про вироблення навичок); схарактеризовано особливості та риси енотек, музеїв виноробства та фестивалів; наведено приклади класифікації “винних" турів (групові, індивідуальні, гібриди першого і другого). Подано дані про структуру “винного” туру (переїзд до місця початку подорожі, трансфер, засоби 
розміщення, засоби харчування, екскурсійні об’єкти). Наведено перелік додаткових послуг, а також приклади автоподорожей по “винних” дорогах Франції, італійських “винних” маршрутах.

Описані “винні" тури країнами Європи, зокрема на Кіпрі (історія найвідоміших марок, проведення фестивалів, “винних” маршрутів, робота Музею вина).

Розкрито зміст екскурсій на грецькі виноробні, а також зв’язок між вином, культурою італійців та їхнім характером. Схарактеризовано конкурсні засади щорічної церемонії відзначення кращого ресторану для “винного” туризму; центрів культури вина “винних" маєтків Італії. Сконцентровано увагу на історії бренду “К'янті”, виробництві граппи та інших винних напоїв.

Розглянуто свято збору винограду в Іспанії (термін, місцезнаходження, програма проведення, “винуватець” свята). Відзначено особливості клімату та грунтів півдня Іспанії як чинників вирощування лози “паломіно”, роль та значення шляхетної плісняви у технології виробництва хересу. Схарактеризовано виноробні регіони Іспанії, найбільший музей вина світу, специфічні засоби розміщення “бодеги”, симбіоз готелів SPA та ресторанів, рекреаційну досяжність Панадесу.

Наведено приклади виробництва оригіналу порто-сонячного нектару Португалії в долині Доуру. Зауважено додаткові мотивації щодо відвідування “винних” турів у Португалії. Подано дані про культуру споживання вина у Франції. Схарактеризовано “винні” тури у Бордо, Шампані, Луарській долині та Бургундії, Ельзасі і “винні” марафони у Медоку. Описано особливості “винних" турів у Німеччині, класи якості вин, виноробні області, “винні” парки відпочинку. Схарактеризовано Женевський виноробний регіон Швейцарії, що входить до списку світової спадщини ЮНЕСКО. Сконцентровано увагу на “винних" турах Угорщиною (22 виноробних регіони). Розкрито малоосвоєні напрями “винного” туризму у Грузії. Розглянуто “винні” тури Закарпаттям та Одеською областю України.

Ключові слова: “винні” різновиди гастрономічних турів як напрям рекреаційної діяльності. 